\title{
Effect of oxidoreduction potential on aroma biosynthesis by lactic acid bacteria in nonfat yogurt
}

\author{
F. Martin, ${ }^{\star}$ R. Cachon, ${ }^{\star}$ K. Pernin, $\dagger$ J. De Coninck, ${ }^{\star}$ P. Gervais, ${ }^{*}$ E. Guichard, $\dagger$ and N. Cayot ${ }^{1}$ \\ *Laboratoire de Génie des Procédés Microbiologiques et Alimentaires, EA 1684, AgroSup Dijon-Université de Bourgogne, INRA, \\ 17 rue Sully, 21065 Dijon, France \\ †Unité Mixte de Recherche, 1129 FLAVIC, AgroSup Dijon-INRA-UB, 17 rue Sully, 21065 Dijon, France
}

\begin{abstract}
The aim of this study was to investigate the effect of oxidoreduction potential (Eh) on the biosynthesis of aroma compounds by lactic acid bacteria in non-fat yogurt. The study was done with yogurts fermented by Lactobacillus bulgaricus and Streptococcus thermophilus. The Eh was modified by the application of different gaseous conditions (air, nitrogen, and nitrogen/ hydrogen). Acetaldehyde, dimethyl sulfide, diacetyl, and pentane-2,3-dione, as the major endogenous odorant compounds of yogurt, were chosen as tracers for the biosynthesis of aroma compounds by lactic acid bacteria. Oxidative conditions favored the production of acetaldehyde, dimethyl sulfide, and diketones (diacetyl and pentane-2,3-dione). The Eh of the medium influences aroma production in yogurt by modifying the metabolic pathways of $L b$. bulgaricus and Strep. thermophilus. The use of Eh as a control parameter during yogurt production could permit the control of aroma formation.
\end{abstract}

Key words: oxidoreduction potential, lactic acid bacteria, bacterial metabolism, volatile compound

\section{INTRODUCTION}

Yogurt is one of the most popular fermented dairy products. The manufacture of yogurt has previously been reviewed by several researchers (Tamine and Robinson, 1988; Robinson and Tamine, 1993; Mulvihill and Grufferty, 1995; Tamine and Marshall, 1997). Additionally, according to the French standard (Codex Alimentarius, 2003), yogurt must be fermented by a mixed culture of 2 lactic acid bacteria (LAB): Lactobacillus bulgaricus and Streptococcus thermophilus. The important features of LAB are rapid acidification, microbial preservation of the milk, texturing capacities, health benefits, and formation of specific flavors (RuasMadiedo et al., 2002). Milk lactose is metabolized by Lb. bulgaricus and Strep. thermophilus to yield lactic

Received April 25, 2010.

Accepted November 11, 2010.

${ }^{1}$ Corresponding author: n.cayot@enesad.fr acid and small amounts of aroma compounds (e.g., ketones, acids, furans, aldehydes, sulfur compounds, and other compounds; $10-50 \mathrm{mg} / \mathrm{kg}$ ). Indeed, the aroma of yogurt is a balance between numerous volatile organic compounds, but only a handful of compounds are reported to have a significant effect on the perceived aroma (Imhof et al., 1995). In fact, among 32 compounds quantified by dynamic headspace analysis, only diacetyl and pentane-2,3-dione were present at concentrations $>1 \mathrm{mg} / \mathrm{kg}$ (Imhof et al., 1995). Applying the concept of odor unit values, which they defined as the ratio of the concentration in the product to the respective perception threshold values, Imhof et al. (1994b) estimated the effect of each volatile compound on the resulting aroma of the end product. Dimethyl sulfide, diacetyl, and pentane-2,3-dione were reported to have significant effects on the aroma of yogurt. Like Imhof et al. (1995), Ott et al. (1997) used GC-olfactometry and confirmed that acetaldehyde, dimethyl sulfide, diacetyl, and pentane-2,3-dione had the strongest effects on yogurt aroma.

One of the precursors of flavor compounds in milk is casein, although flavor compounds can also derive from fatty acids and sugars. The proteolytic system of LAB degrades casein into its constituent amino acids, which can then be converted into flavor compounds (Marilley and Casey, 2004; Smit et al., 2005; Ardö, 2006; Liu et al., 2008). Three main metabolic pathways have been shown to lead to the formation of acetaldehyde (Figure 1a; Ott et al., 2000a): reduction of glucose through the glycolytic pathway (Lees and Jago, 1976a), 2-deoxyribose-5-phosphate by the degradation of DNA (Lees and Jago, 1977; Raya et al., 1986a), and threonine aldolase (Lees and Jago, 1976b; Raya et al., 1986b). For diketones (Figure 1a), the condensation of pyruvate and activated acetaldehyde leads to 2-acetolactate, and the condensation of 2-ketobutyrate and activated acetaldehyde leads to 2-aceto-hydroxybutyrate (Ramos et al., 1994). These 2 precursors (2-acetolactate and 2-aceto-hydroxybutyrate) are converted into diketones in the presence of oxygen, and diacetyl (butane-2,3dione) and pentane-2,3-dione, respectively. Moreover, acetoin produced from aspartic acid can be oxidized 
(a)

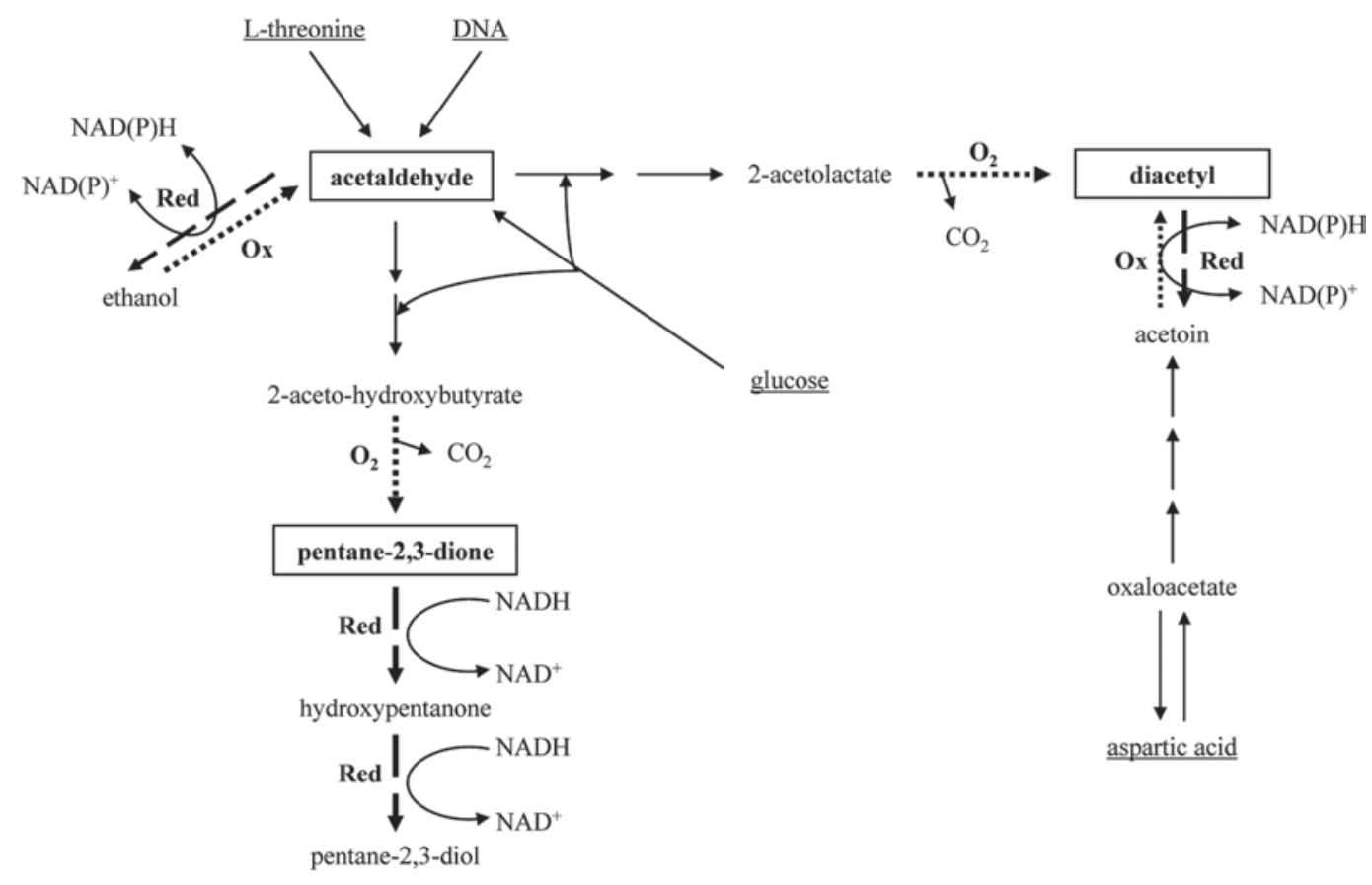

(b)

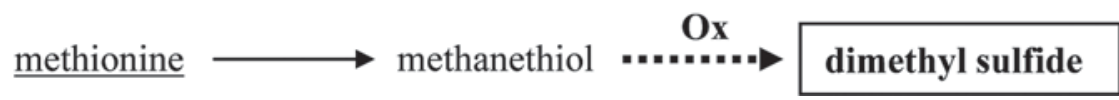

Figure 1. Tentative synthetic overview of the metabolic pathways leading to acetaldehyde, diacetyl, and pentane-2,3-dione (a) and to dimethyl sulfide (b). Ox $=$ chemical oxidation; $\mathrm{Red}=$ chemical reduction.

into diacetyl (Ardö, 2006), and diacetyl and pentane2,3-dione can also be reduced into acetoin and into hydroxypentanone, respectively (Ott et al., 2000b). Finally, dimethyl sulfide is obtained by the oxidation of methanethiol, which comes from methionine (Figure 1b; Singh et al., 2003).

Lactic acid bacteria can be affected by a lot of environmental factors including oxidoreduction potential (Eh). The Eh of a solution corresponds to the overall availability of electrons in solution. The electrochemical measurement of Eh is not new but it has attracted little attention as a control parameter in fermentation processes because of the sensitivity of its measurement. However, Eh is already indirectly taken into account in the industrial environment through oxygen, whose inhibitory effect on lactic acid bacteria is well known. Indeed, oxygen modifies the growth capacity of microorganisms and the formation of end products, and so may participate in the quality of fermented products (Dave and Shah, 1997; Rödel and Scheuer, 2000; van Dijk et al., 2000). Among fermented products, dairy products have recently been shown to be affected by Eh (Abraham et al., 2007; Cachon et al., 2007). In particular, Cachon et al. (2007) showed that the sensory properties of a fermented dairy product can be modified by the use of gases that change the Eh of milk. Milk in air is an oxidizing medium, and nitrogen (a neutral gas) can be used to remove oxygen from milk. Even so, the milk Eh remains oxidizing, and hydrogen provides a reducing Eh $(<0)$. Other studies have indicated that Eh could have a great effect on flavor formation by LAB by modifying the direction of metabolic pathways (Riondet et al., 2000; Wang et al., 2000), and it has been shown that a negative Eh is required for the development and stability of flavor in cheese, especially via the production of volatile sulfhydryl compounds (Green and Manning, 1982; Kristoffersen, 1985). However, little is known of the effect of Eh on aroma formation pathways of LAB in yogurt.

The aim of the present study was to determine to what extent Eh can affect the metabolic pathways involved in the production of these aroma compounds in 
Lb. bulgaricus and Strep. thermophilus. For this purpose, the 4 aroma compounds (acetaldehyde, dimethyl sulfide, diacetyl, and pentane-2,3-dione) were chosen as metabolic tracers of LAB metabolism, and 4 different $\mathrm{Eh}_{7}$ (Eh value standardized to $\mathrm{pH} 7$ ) values were applied to the milk: $+433 \mathrm{mV}$ in milk gassed with air, $+405 \mathrm{mV}$ for nonbubbled air, $+283 \mathrm{mV}$ for milk gasses with nitrogen, and $-349 \mathrm{mV}$ for milk gassed with $\mathrm{N}_{2}$ and $\mathrm{H}_{2}$. The aroma compounds produced by LAB in yogurt were extracted using the solid-phase microextraction technique on the headspace (HS-SPME) and analyzed using GC-MS.

\section{MATERIALS AND METHODS}

\section{Microorganisms and Culture Conditions}

The strains used in this study, Lactobacillus delbrueckii ssp. bulgaricus LB 340 and Streptococcus thermophilus TA 60, were provided by the Microbiological and Food Processes Engineering Laboratory (EA 1684, Dijon, France). The de Man, Rogosa, and Sharpe (MRS) and M17 media used for bacterial culture were supplied by Difco Laboratories (Elancourt, France).

The bacteria were stored at $-80^{\circ} \mathrm{C}$ in MRS medium containing $30 \%$ (vol/vol) glycerol for Lb. bulgaricus and in M17 lactose medium containing $30 \%$ (vol/vol) glycerol for Strep. thermophilus. These cells were inoculated into $10 \mathrm{~mL}$ of MRS lactose medium for Lb. bulgaricus and into $10 \mathrm{~mL}$ of M17 lactose medium for Strep. thermophilus. The cultures were incubated overnight at $37^{\circ} \mathrm{C}$, and $1 \%$ was used to inoculate $100 \mathrm{~mL}$ of their respective media. The flasks were incubated in static conditions, and the optical density was followed at 600 nm (Helios Epsilon, Thermo Spectronic, Cambridge, $\mathrm{UK})$.

\section{Preparation of Nonfat Yogurt Under Different Eh Conditions}

Organic UHT skim milk was purchased at a local market (Lactel, Laval, France) and stored at room temperature. For each batch of milk, total nitrogen content was estimated by the Kjeldahl procedure (Rowland, 1938) and was found to be constant for all milk samples $(5.45 \mathrm{~g} / \mathrm{L} \pm 0.15)$, which corresponded to 31 to $33 \mathrm{~g} / \mathrm{L}$ of protein, using the conversion coefficient $\mathrm{K}=6.36$ and 5 to $10 \%$ NPN (15\% maximum). Low-heat skim milk powder was kindly supplied by Eurosérum (St-Martin Belle Roche, France). This powder was stored at $4^{\circ} \mathrm{C}$ in sealed plastic bags under a nitrogen atmosphere to limit oxidation. In all experiments, milk powder from the same batch was added ( $2 \% \mathrm{wt} / \mathrm{vol})$ to fortify the liquid skim milk (almost $7 \mathrm{~g} / \mathrm{L}$ of protein added).
Table 1. Main characteristics of yogurts made under the different oxidoreduction potential (Eh) conditions ${ }^{1}$

\begin{tabular}{lll}
\hline $\begin{array}{l}\text { Gaseous } \\
\text { condition }\end{array}$ & $\begin{array}{c}\mathrm{Eh}_{7} \text { in milk } \\
(\mathrm{mV})\end{array}$ & $\begin{array}{c}\mathrm{Eh}_{7} \text { in yogurt at } \\
\mathrm{pH} 4.6(\mathrm{mV})\end{array}$ \\
\hline Ambient air & $+405^{\mathrm{a}} \pm 22$ & $+171^{\mathrm{a}} \pm 2$ \\
Bubbled air & $+433^{\mathrm{a}} \pm 6$ & $+241^{\mathrm{b}} \pm 8$ \\
Bubbled $\mathrm{N}_{2}$ & $+283^{\mathrm{b}} \pm 13$ & $+139^{\mathrm{c}} \pm 5$ \\
Bubbled $\mathrm{N}_{2}-\mathrm{H}_{2}$ & $-349^{\mathrm{c}} \pm 6$ & $-309^{\mathrm{d}} \pm 10$ \\
\hline
\end{tabular}

${ }^{\mathrm{a}-\mathrm{d}}$ Values with different superscript letters within a column indicate that groups were significantly different at the risk $\alpha$ of $5 \%$ (ANOVA test).

${ }^{1}$ Values are means of experiments carried out in triplicate; $\mathrm{Eh}_{7}=\mathrm{Eh}$ standardized to $\mathrm{pH} 7$.

The fortified milk was stirred for $4 \mathrm{~h}$ after addition of skim milk powder and heated to $45^{\circ} \mathrm{C}$. Then, the fortified milk was processed under different gaseous conditions. Different Eh conditions were obtained by gas bubbling during the $4 \mathrm{~h}$ at a gas flow of $20 \mathrm{~mL} / \mathrm{min}$ : air, nitrogen, or nitrogen plus $4 \%$ (vol/vol) hydrogen. For $\mathrm{N}_{2}$ and $\mathrm{N}_{2}-\mathrm{H}_{2}$ conditions, gas bubbling was done in an anaerobic chamber (Bactron I, Sheldon Manufacturing, Cornelius, OR). To check the effect of gas bubbling, some experiments were also done on nonbubbled milk (ambient oxidizing condition). After the bubbling procedure, when applied, the mixture was acidified using $1.10^{7} \mathrm{cfu} / \mathrm{mL}$ of starter culture. Hungate tubes (Dutscher, Brumath, France), which prevent exposure to oxygen during storage, were partially filled with 10 $\mathrm{mL}$ of the milk. The $\mathrm{pH}$ was continually measured; when it reached 4.6 the yogurts were cooled to $4^{\circ} \mathrm{C}$ in a bath of ice water for $1 \mathrm{~h}$ and stored at $4^{\circ} \mathrm{C}$ pending further analyses. The main characteristics of the yogurts are detailed in Table 1.

\section{Eh and pH Measurements}

To measure $\mathrm{pH}$, a combined autoclavable $\mathrm{pH}$ electrode (Mettler-Toledo SARL, Paris, France) was used. The $\mathrm{pH}$ electrode was calibrated using $\mathrm{pH} 7$ and $\mathrm{pH} 4$ calibration buffers and cleaned after each run by using a pepsin/HCl solution (Poly Labo, Paris, France).

Oxidoreduction potential was measured by combined autoclavable redox electrodes (Mettler-Toledo SARL). The electrodes had a ceramic diaphragm and a platinum band. Before each use, the redox electrodes were polished with fine alumina powder (aluminum oxide, VWR Prolabo, Lyon, France) to restore the platinum surface and were controlled in tap water. Three measurements in tap water were compared and needed to be included in the confidence interval around their mean value (calculated at $20 \mathrm{mV}, 95 \% \mathrm{CI}$ ) to ensure correct measurement (Abraham et al., 2007). For $\mathrm{N}_{2}$ and $\mathrm{N}_{2}-\mathrm{H}_{2}$ conditions, $\mathrm{pH}$ and Eh were measured in the anaerobic chamber (Bactron I). 


\section{Data Acquisition of $\mathrm{pH}$ and Eh Profiles}

The redox and $\mathrm{pH}$ electrodes and the temperature sensor were connected to an interface (ELIT multichannel pH-meter/redox-meter computer interface, Bioblock, Illkirch, France), which enabled real-time data acquisition on a computer. The $\mathrm{pH}$ and the measured redox potential $(\mathbf{E m}, \mathrm{mV})$ values were followed simultaneously. The Em values were converted into Eh values according to the standard redox potential of the reference electrode (Er) using the equation

$$
\mathrm{Eh}=\mathrm{Em}+\mathrm{Er},
$$

where Eh is the redox potential related to the normal hydrogen electrode, Em is the measured redox potential, and Er is the redox potential of the reference electrode; Er varies with temperature and the type of electrode. In our study, the redox electrode (Pt 4805$\mathrm{SC}$, Mettler-Toledo) had an $\mathrm{Er}=192 \mathrm{mV}$ at $45^{\circ} \mathrm{C}$. Measured potential values were $\mathrm{pH}$ dependent. It was possible to overcome $\mathrm{pH}$ dependency by applying the Leistern and Mirna (1959) equation:

$$
\mathrm{Eh}_{7}=\mathrm{Eh}-[(7-\mathrm{pH}) \alpha],
$$

where $\mathrm{Eh}_{7}(\mathrm{mV})$ is the redox potential $\mathrm{Eh}$ at $\mathrm{pH} 7, \mathrm{Eh}$ is the redox potential related to the normal hydrogen electrode, and $\alpha(\mathrm{mV} / \mathrm{pH}$ unit) is the Nernst Eh- $\mathrm{pH}$ correlation factor, which must be determined experimentally (Jacob, 1970) by measuring $\mathrm{pH}$-related variations in Eh using lactic acid or $\mathrm{NaOH}$. For the skim milk used in this study, we measured an Eh variation of $40 \mathrm{mV} / \mathrm{pH}$ unit at $45^{\circ} \mathrm{C}$, which is in agreement with the results obtained by Cachon et al. (2002).

The $\mathrm{Eh}_{7}$ values were $+433 \mathrm{mV}( \pm 6 \mathrm{mV})$ in the milk gassed with air, $+405 \mathrm{mV}( \pm 22 \mathrm{mV})$ in the nongassed milk, $+283 \mathrm{mV}( \pm 13 \mathrm{mV})$ in the milk gassed with nitrogen, and $-349 \mathrm{mV}( \pm 6 \mathrm{mV})$ in the milk gassed with the $\mathrm{N}_{2}-\mathrm{H}_{2}$ mixture.

\section{Reference ${ }^{13} \mathrm{C}$-Labeled Aroma Compounds}

The following reference compounds were used to quantify volatile compounds: acetaldehyde- ${ }^{13} \mathrm{C}_{2}$ (purity: 99\%; Sigma-Aldrich, Saint-Quentin Fallavier, France), dimethyl sulfide- ${ }^{13} \mathrm{C}_{2}$ (purity: 99\%; Sigma-Aldrich), diacetyl- ${ }^{13} \mathrm{C}_{4}$ (purity: 97.5\%; Aromalyse, Longvic, France), and pentane-2,3-dione $-{ }^{13} \mathrm{C}_{4}$ (purity: $98.1 \%$; Aromalyse).

\section{HS-SPME Sampling}

The yogurt samples made under the 4 Eh conditions (air, bubbled air, bubbled $\mathrm{N}_{2}$, bubbled $\mathrm{N}_{2}-\mathrm{H}_{2}$ ) were ana- lyzed after 1, 7, 14, 21, and $28 \mathrm{~d}$ of storage. Each yogurt sample was analyzed in triplicate. Volatile compounds were sampled in the headspace of the yogurts using the SPME technique according to a modified method of Chammas et al. (2006). The SPME fibers comprised a 2-cm fiber coated with $75-\mu \mathrm{m}$ carboxen on polydimethylsiloxane bonded to a flexible, fused-silica core ( $\mathrm{Su}-$ pelco, Bellefonte, PA). The fibers were conditioned in a splitless/split GC injector port $\left(2 \mathrm{~h}\right.$ at $\left.300^{\circ} \mathrm{C}\right)$ before first use and reconditioned at $270^{\circ} \mathrm{C}$ for $10 \mathrm{~min}$ before each extraction. The yogurts $(7.5 \mathrm{~g})$, a saturated solution of $\mathrm{NaCl}(3.5 \mathrm{~g})$, and the four ${ }^{13} \mathrm{C}$-labeled aroma compounds were introduced into a $10-\mathrm{mL}$ vial, which was immediately sealed with a silicone rubber Teflon cap. For this purpose, water solutions of ${ }^{13} \mathrm{C}$-labeled aroma compounds were used. The concentrations were chosen to obtain peak surfaces similar to those of the corresponding aroma compounds in yogurt. The concentrations and amounts added to the yogurt were as follows: for acetaldehyde and for dimethyl sulfide, 18 $\mu \mathrm{g} / \mathrm{mL}$ and $25 \mu \mathrm{L}$; for diacetyl, $180 \mu \mathrm{g} / \mathrm{mL}$ and $100 \mu \mathrm{L}$; for pentane-2,3-dione, $90 \mu \mathrm{g} / \mathrm{mL}$ and $100 \mu \mathrm{L}$. The vials were equilibrated for $30 \mathrm{~min}$ in a thermostatic bath at $55^{\circ} \mathrm{C}$ and agitated at $500 \mathrm{rpm}$. The SPME fiber was exposed to the yogurts headspace for $40 \mathrm{~min}$.

\section{GC-MS Analyses}

After sampling, the SPME fibers containing the headspace volatile compounds were analyzed on a gas chromatograph model 6890 (Hewlett Packard, Palo Alto, CA) equipped with a splitless/split injector and coupled with a mass selective detector model 5973 (Agilent Technologies, Palo Alto, CA). The fibers were immediately inserted into the GC injection port equipped with a $0.75-\mathrm{mm}$ i.d. liner (Supelco) and thermally desorbed for $3 \mathrm{~min}$ at $270^{\circ} \mathrm{C}$. After desorption, each fiber was placed for $10 \mathrm{~min}$ in an injection port at $270^{\circ} \mathrm{C}$ to eliminate any compound from the fiber. A fused-silica capillary column CP-Porabond Q column (length: $25 \mathrm{~m}$; internal diameter: $0.32 \mathrm{~mm}$; film thickness: $5 \mu \mathrm{m}$; Varian, Middelburg, the Netherlands) was used. Operating conditions were as follows: injection system, splitless time, $3 \mathrm{~min}$; injection temperature, $240^{\circ} \mathrm{C}$; temperature program from $40^{\circ} \mathrm{C}$ to $165^{\circ} \mathrm{C}$ at $4^{\circ} \mathrm{C} / \mathrm{min}$, then $165^{\circ} \mathrm{C}$ to $280^{\circ} \mathrm{C}$ at $15^{\circ} \mathrm{C} / \mathrm{min}$, and finally held constant for $5 \mathrm{~min}$. Helium was used as the carrier gas in the constant flow mode $(1.7 \mathrm{~mL} / \mathrm{min})$ with a linear velocity of $52 \mathrm{~cm} / \mathrm{s}$. Mass spectrometry was operated in the electron impact mode $(70 \mathrm{eV})$; the ion source temperature was set at $230^{\circ} \mathrm{C}$ and transfer line at $280^{\circ} \mathrm{C}$.

Identification of Volatile Compounds. The mass spectrometer scanned mass from $\mathrm{m} / z 29$ to 350 . The identification of the volatile compounds (acetal- 
dehyde, acetaldehyde- ${ }^{13} \mathrm{C}_{2}$, dimethylsulfide, dimethyl sulfide $-{ }^{13} \mathrm{C}_{2}$, diacetyl, diacetyl- ${ }^{13} \mathrm{C}_{4}$, pentane-2,3-dione, pentane-2,3-dione- ${ }^{13} \mathrm{C}_{4}$ ) was carried out by comparison of their mass spectra with those of the pure reference compounds injected in the same conditions, and using the mass spectra libraries (Wiley, NIST, INRA databases).

Quantitative Measurements. In agreement with the full scan spectrum and the time retention, these volatile compounds were quantified by selected ion monitoring (SIM) mode analysis; $\mathrm{m} / z 29$ and 44 for acetaldehyde; $m / z 30$ and 46 for acetaldehyde- ${ }^{13} \mathrm{C}_{2}$; $\mathrm{m} / z 47$ and 62 for dimethylsulfide; $\mathrm{m} / z 48$ and 64 for dimethylsulfide $-{ }^{13} \mathrm{C}_{2} ; \mathrm{m} / z 43$ and 86 for diacetyl; $\mathrm{m} / \mathrm{z}$ 45 and 90 for diacetyl- ${ }^{13} \mathrm{C}_{4} ; \mathrm{m} / z$ 43, 57 and 100 for pentane-2,3-dione; and $\mathrm{m} / z 45,57$ and 102 for pentane2,3-dione- ${ }^{13} \mathrm{C}_{4}$.

The addition of ${ }^{13} \mathrm{C}$-labeled aroma compounds to each sample before the extraction of aroma compounds of interest allowed us to verify the reproducibility of the extraction efficiency. Indeed, the concentration of the labeled aromas found in the yogurt was the same regardless of the Eh condition. We found that in a matrix such as water, the extraction yield for these ${ }^{13} \mathrm{C}$-labeled aroma compounds was the same as when they were added to the different yogurts. These results allow us to confirm that with the method used, the matrix had no retention effect on ${ }^{13} \mathrm{C}$-labeled aroma compounds and thus neither on the aroma compounds that we set out to quantify in the yogurt. Calibration curves were plotted to calculate the concentration of aromas depending on the area of peak obtained by GC-MS.

\section{Statistical Analysis}

Statistical analyses of the results were carried out with Stat box software (version 6.5, Grimmer Logiciels, Issy les Moulineaux, France). An ANOVA test was used to compare averages of $\mathrm{Eh}_{7}$ and averages of aroma quantification. Differences were considered significant for the risk $\alpha \leq 0.05$.

\section{RESULTS}

\section{Evolution of $\mathrm{pH}$ and Redox Potential}

The $\mathrm{Eh}_{7}$ measured in yogurts at the beginning and the end of the acidification is given in Table 1. Four different $\mathrm{Eh}_{7}$ values were obtained in the milk (at $\mathrm{pH}$ 6.8): $+33 \mathrm{mV}$ (milk gassed with air), $+405 \mathrm{mV}$ (ungassed milk), $+283 \mathrm{mV}$ (milk gassed with $\mathrm{N}_{2}$ ) and $-349 \mathrm{mV}$ (milk gassed with $\mathrm{N}_{2}-\mathrm{H}_{2}$ ). For all Eh conditions except $\mathrm{N}_{2}-\mathrm{H}_{2}, \mathrm{Eh}_{7}$ decreased during acidification. The values obtained for the $4 \mathrm{Eh}_{7}$ conditions in the yogurts were the following (at $\mathrm{pH} 4.6$ ): $+241 \mathrm{mV}$ (milk gassed with air), $+171 \mathrm{mV}$ (ungassed milk), $+139 \mathrm{mV}$ (milk gassed with $\mathrm{N}_{2}$ ) and $-309 \mathrm{mV}$ (milk gassed with $\mathrm{N}_{2}-\mathrm{H}_{2}$ ). This decrease in $\mathrm{Eh}_{7}$ values during the growth of LAB could have been caused by the uptake of oxidizing compounds such as oxygen (for air and bubbled air) from the medium, and the production of metabolites with reducing characteristics in the milk (Jacob, 1970). For yogurts made under $\mathrm{N}_{2}-\mathrm{H}_{2}$, Eh did not vary (approximately $-335 \mathrm{mV})$.

\section{Quantification of Volatile Compounds After $1 \mathrm{~d}$ of Storage}

We evaluated the effect of different Eh conditions on the biosynthesis of 4 aromas by LAB, after $1 \mathrm{~d}$ of storage. The amounts of each of the 4 aroma compounds quantified by SPME-GC-MS are reported in Figure 2.

For the yogurts made under air (standard yogurt), the concentration of diacetyl was higher than that of pentane-2,3-dione, which was higher than that of dimethyl sulfide. The lowest concentration was that of acetaldehyde, whereas, in the literature, the lowest concentration reported among these 4 aroma compounds was for dimethyl sulfide $(0.013-0.070 \mathrm{mg} / \mathrm{kg}$, measured by dynamic and trapped headspace GC; Imhof et al., 1994b; Ott et al., 1999). Compared with the published data for yogurts made under air, the concentration of dimethyl sulfide was clearly higher in our experiments $(10 \mathrm{mg} / \mathrm{kg})$. For acetaldehyde, published concentrations were higher $(0.7-15.9 \mathrm{mg} / \mathrm{kg})$ than in our standard yogurt $(0.18 \mathrm{mg} / \mathrm{kg})$. In the literature, concentrations of diacetyl and 2,3-pentandione were 0.31 to $17.3 \mathrm{mg} / \mathrm{kg}$ and 0.02 to $4.5 \mathrm{mg} / \mathrm{kg}$, respectively. In our standard yogurt, the concentrations were higher: $162 \mathrm{mg} / \mathrm{kg}$ for diacetyl and $115 \mathrm{mg} / \mathrm{kg}$ for pentane-2,3-dione.

Compared with standard yogurts, those made under bubbled air had significantly higher concentrations of both acetaldehyde and diacetyl. The concentration of dimethyl sulfide was significantly lower for bubbled air yogurts, whereas that of pentane-2,3-dione was the same.

For yogurts made without air (i.e., bubbled $\mathrm{N}_{2}$ ), the acetaldehyde concentration was the same as that in yogurts made under bubbled air. The dimethyl sulfide concentration was lower than in yogurts made under air (bubbled or not). The concentration of diacetyl was the same as in standard yogurts, and the concentration of pentane-2,3-dione was not significantly different from that in yogurts made under air (bubbled or not).

Finally, under reducing conditions (bubbled $\mathrm{N}_{2}-\mathrm{H}_{2}$ ), the concentrations of acetaldehyde and pentane-2,3- 
dione were the same as those in standard yogurts. The concentration of dimethyl sulfide was the same as that in yogurts made without oxygen, and the concentration of diacetyl was significantly lower than under the other 3 Eh conditions.

\section{Evolution of Quantification of Volatile Compounds During $28 \mathrm{~d}$ of Storage}

The yogurts were kept in Hungate tubes at $4{ }^{\circ} \mathrm{C}$ for 28 d. Unlike simple glass vials, Hungate tubes can prevent exposure of the contents to oxygen. The gas conditioning applied to the milk before the LAB acidification was then assumed to be constant during storage. The effect of different Eh conditions was studied on the 4 aroma compounds of the yogurts during $28 \mathrm{~d}$ of storage. The results of the quantification of the aroma compounds after $1,7,14,21$, and $28 \mathrm{~d}$ of storage are presented in Table 2. For standard yogurt, the quantities of acetaldehyde and dimethyl sulfide produced were relatively stable during the storage, whereas the concentration of diketones decreased significantly.

For yogurts made under bubbled air, the aroma profiles remained almost constant. During storage, the concentration of acetaldehyde decreased slightly, whereas that of dimethyl sulfide increased slightly. The concentration of diketones decreased significantly.

For yogurts made without oxygen (under bubbled $\mathrm{N}_{2}$ ), the quantities of acetaldehyde, diacetyl, and pen- (a)

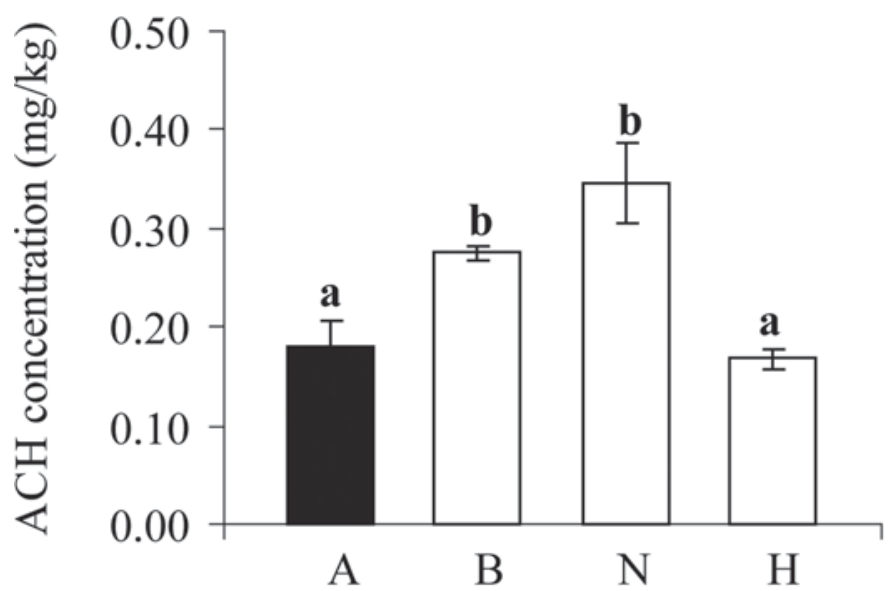

(c)

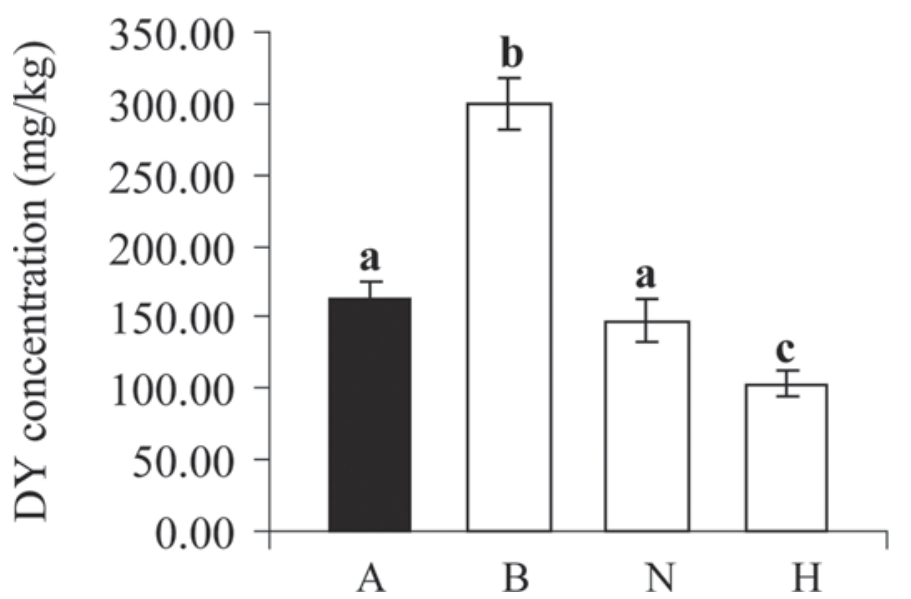

(b)

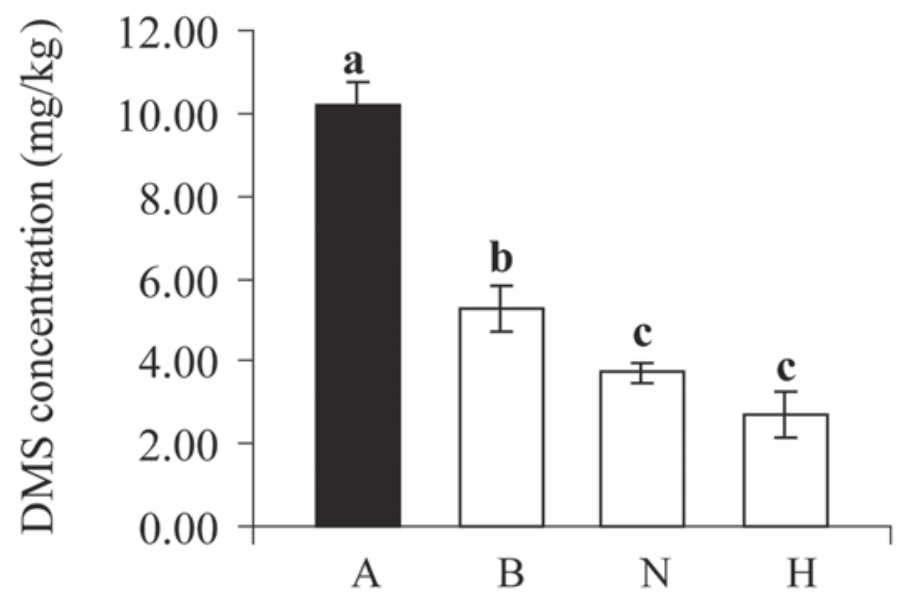

(d)

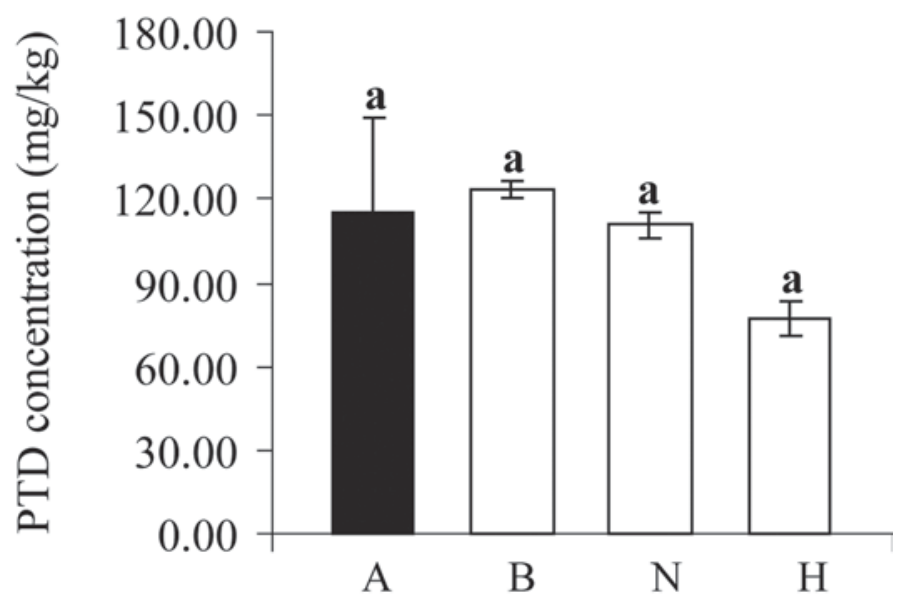

Figure 2. Average amounts (3 replicates) of the aroma compounds $(\mathrm{mg} / \mathrm{kg})$ quantified in the headspace of the yogurts made under the different oxidoreduction (Eh) conditions $\left(\mathrm{A}=\right.$ air, $\mathrm{B}=$ bubbled air, $\mathrm{N}=$ bubbled $\mathrm{N}_{2}$, and $\mathrm{H}=$ bubbled $\left.\mathrm{N}_{2}-\mathrm{H}_{2}\right)$ after $1 \mathrm{~d}$ of storage: a) acetaldehyde $(\mathrm{ACH})$; b) dimethyl sulfide (DMS); c) diacetyl (DY), and d) pentane-2,3-dione (PTD). Values are means of experiments carried out in triplicate; different letters $(\mathrm{a}, \mathrm{b}, \mathrm{c})$ indicate that groups within a panel are significantly different at the risk $\alpha$ of $5 \%$ (ANOVA test). 
Table 2. Evolution of average amounts of the aroma compounds quantified in the headspace of the yogurts made under the different oxidoreduction potential (Eh) conditions during $28 \mathrm{~d}$ of storage $^{1}$

\begin{tabular}{|c|c|c|c|c|}
\hline \multirow{2}{*}{$\begin{array}{l}\text { Eh condition and } \\
\text { storage period }\end{array}$} & \multicolumn{4}{|c|}{ Aroma compound (mg/kg) } \\
\hline & Acetaldehyde & Dimethyl sulfide & Diacetyl & Pentane-2,3-dione \\
\hline $1 \mathrm{~d}$ & $0.18^{\mathrm{a}} \pm 0.02$ & $10.16^{\mathrm{a}} \pm 0.59$ & $162.08^{\mathrm{a}} \pm 13.49$ & $115.25^{\mathrm{a}} \pm 33.70$ \\
\hline $7 \mathrm{~d}$ & $0.13^{\mathrm{ab}} \pm 0.02$ & $10.16^{\mathrm{a}} \pm 0.99$ & $115.55^{\mathrm{cb}} \pm 5.13$ & $84.33^{\mathrm{ab}} \pm 1.86$ \\
\hline $14 \mathrm{~d}$ & $0.10^{\mathrm{b}} \pm 0.00$ & $9.52^{\mathrm{a}} \pm 0.42$ & $91.63^{\mathrm{c}} \pm 8.02$ & $71.56^{\mathrm{ab}} \pm 4.49$ \\
\hline $21 \mathrm{~d}$ & $0.18^{\mathrm{a}} \pm 0.00$ & $13.06^{\mathrm{b}} \pm 1.21$ & $141.29^{\mathrm{ab}} \pm 11.77$ & $65.19^{\mathrm{b}} \pm 5.49$ \\
\hline $1 \mathrm{~d}$ & $0.28^{\mathrm{a}} \pm 0.00$ & $5.27^{\mathrm{a}} \pm 0.53$ & $299.90^{\mathrm{a}} \pm 18.37$ & $123.47^{\mathrm{a}} \pm 3.23$ \\
\hline $7 \mathrm{~d}$ & $0.14^{\mathrm{b}} \pm 0.01$ & $6.34^{\mathrm{ab}} \pm 0.30$ & $127.58^{\mathrm{bc}} \pm 3.93$ & $83.98^{\mathrm{b}} \pm 2.20$ \\
\hline $14 \mathrm{~d}$ & $0.11^{\mathrm{b}} \pm 0.01$ & $6.85^{\mathrm{b}} \pm 0.32$ & $104.23^{\mathrm{b}} \pm 4.66$ & $78.10^{\mathrm{b}} \pm 3.15$ \\
\hline $21 \mathrm{~d}$ & $0.24^{\mathrm{a}} \pm 0.02$ & $9.33^{\mathrm{c}} \pm 0.55$ & $143.84^{\mathrm{c}} \pm 6.69$ & $67.89^{\mathrm{c}} \pm 0.80$ \\
\hline $28 \mathrm{~d}$ & $0.13^{\mathrm{b}} \pm 0.02$ & $6.78^{\mathrm{b}} \pm 0.30$ & $101.91^{\mathrm{b}} \pm 3.03$ & $54.36^{\mathrm{d}} \pm 4.19$ \\
\hline \multicolumn{5}{|l|}{ Bubbled $\mathrm{N}_{2}$} \\
\hline $1 \mathrm{~d}$ & $0.35^{\mathrm{a}} \pm 0.04$ & $3.72^{\mathrm{a}} \pm 0.22$ & $147.79^{\mathrm{a}} \pm 9.91$ & $110.87^{\mathrm{a}} \pm 4.49$ \\
\hline $1 \mathrm{~d}$ & $0.17^{\mathrm{ab}} \pm 0.00$ & $2.71^{\mathrm{a}} \pm 0.57$ & $102.73^{\mathrm{a}} \pm 9.10$ & $76.99^{\mathrm{a}} \pm 5.90$ \\
\hline $7 \mathrm{~d}$ & $0.13^{\mathrm{bc}} \pm 0.02$ & $5.49^{\mathrm{b}} \pm 0.53$ & $89.61^{\mathrm{ab}} \pm 7.70$ & $66.10^{\mathrm{ac}} \pm 2.29$ \\
\hline $14 \mathrm{~d}$ & $0.11^{\mathrm{c}} \pm 0.01$ & $6.07^{\mathrm{bc}} \pm 0.43$ & $74.35^{\mathrm{b}} \pm 5.42$ & $57.60^{\mathrm{bc}} \pm 0.86$ \\
\hline $21 \mathrm{~d}$ & $0.19^{\mathrm{a}} \pm 0.01$ & $7.48^{\mathrm{c}} \pm 0.53$ & $112.09^{\mathrm{a}} \pm 7.82$ & $52.10^{\text {bd }} \pm 0.59$ \\
\hline $28 \mathrm{~d}$ & $0.12^{\mathrm{c}} \pm 0.01$ & $7.22^{\mathrm{c}} \pm 0.63$ & $78.36^{\mathrm{b}} \pm 9.30$ & $40.60^{\mathrm{d}} \pm 7.93$ \\
\hline
\end{tabular}

${ }^{\mathrm{a}-\mathrm{d}}$ Values with different superscript letters within a column indicate that groups were significantly different at the risk $\alpha$ of $5 \%$ (ANOVA test). ${ }^{1}$ Values are means of experiments carried out in triplicate.

tane-2,3-dione decreased during storage, whereas that of dimethyl sulfide increased.

Under reducing conditions (bubbled $\mathrm{N}_{2}-\mathrm{H}_{2}$ ), the aroma profiles during storage were the same as those of yogurts produced without oxygen. The concentration of acetaldehyde, diacetyl, and pentane-2,3-dione decreased, whereas that of dimethyl sulfide increased.

\section{DISCUSSION}

Usually, studies on aroma biosynthesis by LAB take environmental factors such as $\mathrm{pH}$ and temperature into account. However, the Eh of the medium has not previously been considered, although it is thought to affect bacterial metabolism (Riondet et al., 2000; Kieronczyk et al., 2006). In this study, different gaseous conditions were applied to milk to modify the Eh and to study its effect on aroma biosynthesis by Lb. bulgaricus and Strep. thermophilus. For yogurts made under air, the concentrations of dimethyl sulfide, diacetyl, and pentane-2,3-dione were higher than those in published data (Imhof et al., 1994b; Ott et al., 1999), whereas the concentration of acetaldehyde was lower. One explanation for these differences can be proposed: the quantification technique used by Ott et al. (1999) and Imhof et al. (1994b) was dynamic and trapped headspace GC.
This technique requires Tenax traps, which may be saturated, as we showed in a preliminary experiment. Furthermore, in our study, to extract the aroma compounds more completely, a saturated solution of $\mathrm{NaCl}$ was added to the yogurt. Finally, the LAB we used were not the same species as those used by the researchers in the previous studies, which may have resulted in different quantities of the various aroma compounds.

Our study revealed that oxidative Eh conditions clearly stimulated the production of aroma compounds. These results are consistent with the literature. Indeed, Kieronczyk et al. (2006) showed that oxidative conditions favored the production of volatile sulfur compounds such as dimethyl sulfide, and aldehydes such as acetaldehyde. In presence of oxygen, the oxidative decarboxylation of 2-acetolactate and 2-aceto-hydroxybutyrate to respectively diacetyl and pentane-2,3-dione was also favored (Monnet et al., 1994; Boumerdassi et al., 1996; Neijssel et al., 1997; Hugenholtz and Kleerebezem, 1999). The result for diacetyl may be explained by the fact that when LAB grow anaerobically, they mainly dehydrogenate the NADH produced during glycolysis via lactate dehydrogenase activity. Boumerdassi et al. (1996) confirmed that oxygen increases NADH oxidase activity (Condon, 1987), which causes NADH reoxidation to the detriment of activities of lactate de- 
hydrogenase, butanediol dehydrogenase, and acetoin dehydrogenase (Bassit et al., 1993). Then, excess pyruvate is eliminated partially through acetolactate production, which increases production of diacetyl (Boumerdassi et al., 1996).

Our study showed that during storage, the 4 aromas presented different profiles depending on the Eh condition. Under oxidizing conditions $(+170$ to $+245 \mathrm{mV})$, the acetaldehyde concentration was relatively stable during storage, which is consistent with the literature (Imhof and Bosset, 1994; Gardini et al., 1999; Tamine and Robinson, 1999) and the dimethyl sulfide concentration was also stable. Under reducing conditions $(-300$ to $-349 \mathrm{mV})$, the acetaldehyde concentration decreased, whereas that of dimethyl sulfide increased. The metabolic pathways involved in the biosynthesis of sulfur compounds are still unclear. Under reducing conditions, it seems that another pathway promotes the production of dimethyl sulfide and that acetaldehyde may be reduced into ethanol. For diketones, regardless of the Eh conditions, the concentration decreased during storage. Diacetyl and pentane-2,3-dione can be reduced, respectively, into acetoin and into pentane2,3-diol (Ott et al., 2000b).

\section{ACKNOWLEDGMENTS}

This work was done thanks to the Lipids and Aromas Platform in the National Institute of Agronomic Research (Dijon, France) and with financial support from the French government.

\section{REFERENCES}

Abraham, S., R. Cachon, B. Colas, G. Feron, and J. De Coninck. 2007. Eh and $\mathrm{pH}$ gradients in Camembert cheese during ripening: Measurements using microelectrodes and correlations with texture. Int. Dairy J. 17:954-960.

Ardö, Y. 2006. Flavour formation by amino acid catabolism. Biotechnol. Adv. 24:238-242.

Bassit, N., C. Y. Boquien, D. Picque, and G. Corrieu. 1993. Effect of initial oxygen concentration on diacetyl and acetoin production by Lactococcus lactis spp. lactis biovar diacetylactis. Appl. Environ. Microbiol. 59:1893-1897.

Boumerdassi, H., M. Desmazeaud, C. Monnet, C. Y. Boquien, and G. Corrieu. 1996. Improvement of diacetyl production by Lactococcus lactis spp. lactis CNRZ 483 through oxygen control. J. Dairy Sci. 79:775-781.

Cachon, R., G. Feron, C. Delbeau, D. Ibarra, and H. Ledon, inventors. 2007. Process by which the sensory properties of a fermented dairy product are modified, and maturation thereof during the conservation of said product. L'Air Liquide, assignee. European Pat. No. $1,649,955$.

Cachon, R., S. Jeanson, M. Aldarf, and C. Divies. 2002. Characterisation of lactic starters based on acidification and reduction activities. Lait 82:281-288.

Chammas, G. I., R. Saliba, G. Corrieu, and C. Beal. 2006. Characterisation of lactic acid bacteria isolated from fermented milk "laban". Int. J. Food Microbiol. 110:52-61.
Condon, S. 1987. Responses of lactic acid bacteria to oxygen. FEMS Microbiol. Lett. 46:269-280.

Dave, R. I., and N. P. Shah. 1997. Effectiveness of ascorbic acid as an oxygen scavenger in improving viability of probiotic bacteria in yoghurts made with commercial starter cultures. Int. Dairy J. $7: 435-443$.

Codex Alimentarius. 2003. Codex Standard 243: Standard for fermented milks. Milk Products. Vol. 12. Codex Alimentarius, Paris, France.

Gardini, F., R. Lanciotti, M. Elisabetta Guerzoni, and S. Torriani. 1999. Evaluation of aroma production and survival of Streptococcus thermophilus, Lactobacillus delbrueckii ssp. bulgaricus and Lactobacillus acidophilus in fermented milks. Int. Dairy J. 9:125-134.

Green, M., and D. J. Manning. 1982. Development of texture and flavour in cheese and other fermented products. J. Dairy Res. 49:737-748.

Hugenholtz, J., and M. Kleerebezem. 1999. Metabolic engineering of lactic acid bacteria: Overview of the approaches and results of pathway rerouting involved in food fermentations. Curr. Opin. Biotechnol. 10:492-497.

Imhof, R., and J. O. Bosset. 1994. Quantitative GC-MS analysis of volatile flavour compounds in pasteurized milk and fermented milk products applying a standard addition method. Lebensm. Wiss. Technol. 27:265-269.

Imhof, R., H. Glattli, and J. O. Bosset. 1994b. Volatile organic aroma compounds produced by thermophilic and mesophilic mixed strain dairy starter cultures. Lebensm. Wiss. Technol. 27:442-449.

Imhof, R., H. Glättli, and J. O. Bosset. 1995. Volatile organic compounds produced by thermophilic and mesophilic single strain dairy starter cultures. Food Sci. Technol. 28:78-86.

Jacob, H. E. 1970. Redox potential. Pages 91-123 in Methods in Microbiology. J. R. Norris and D. W. Ribbons, ed. Academic Press, New York, NY.

Kieronczyk, A., R. Cachon, G. Feron, and M. Yvon. 2006. Addition of oxidizing or reducing agents to the reaction medium influences amino acid conversion to aroma compounds by Lactococcus lactis. J. Appl. Microbiol. 101:1114-1122.

Kristoffersen, T. 1985. Development of flavor in cheese. Milchwissenschaft 40:197-199.

Lees, G. J., and G. R. Jago. 1976a. Acetaldehyde: An intermediate in the formation of ethanol from glucose by lactic acid bacteria. J. Dairy Res. 43:63-73.

Lees, G. J., and G. R. Jago. 1976b. Formation of acetaldehyde from threonine by lactic acid bacteria. J. Dairy Res. 43:75-83.

Lees, G. J., and G. R. Jago. 1977. Formation of acetaldehyde from 2-desoxy-D-ribose-5-phosphate in lactic acid bacteria. J. Dairy Res. 44:139-144.

Leistern, L., and A. Mirna. 1959. Das redoxpotential von pökelladen. Die Fleischwirtschaft 8:659-666.

Liu, M., A. Nauta, C. Francke, and R. J. Siezen. 2008. Comparative genomics of enzymes in flavor-forming pathways from amino acids in lactic acid bacteria. Appl. Environ. Microbiol. 74:4590-4600.

Marilley, L., and M. G. Casey. 2004. Flavours of cheese products: Metabolic pathways, analytical tools and identification of producing strains. Int. J. Food Microbiol. 90:139-159.

Monnet, C., P. Schmitt, and C. Divies. 1994. Method for assaying volatile compounds by headspace gas chromatography and application to growing starter cultures. J. Dairy Sci. 77:1809-1815.

Mulvihill, D. M., and M. B. Grufferty. 1995. Effect of thermal processing on the coagulability of milk by acid. Pages 188-205 in HeatInduced Changes in Milk. 2nd ed. P. F. Fox, ed. Special Issue No. 9501. International Dairy Federation, Brussels, Belgium.

Neijssel, O. M., J. L. Snoep, and M. J. Teixeira de Mattos. 1997. Regulation of energy source metabolism in streptococci. Soc. Appl. Bacteriol. Symp. Ser. 26:12S-19S.

Ott, A., L. B. Fay, and A. Chaintreau. 1997. Determination and origin of the aroma impact compounds of yogurt flavor. J. Agric. Food Chem. 45:850-858.

Ott, A., J.-E. Germond, M. Baumgartner, and A. Chaintreau. 1999. Aroma comparisons of traditional and mild yogurts: Headspace 
gas chromatography quantification of volatiles and origin of alphadiketones. J. Agric. Food Chem. 47:2379-2385.

Ott, A., J.-E. Germond, and A. Chaintreau. 2000a. Origin of acetaldehyde during milk fermentation using ${ }^{13} \mathrm{C}$-labeled precursors. J. Agric. Food Chem. 48:1512-1517.

Ott, A., J.-E. Germond, and A. Chaintreau. 2000b. Vicinal diketone formation in yogurt: ${ }^{13} \mathrm{C}$ precursors and effect of branched-chain amino acids. J. Agric. Food Chem. 48:724-731.

Ramos, A., K. N. Jordan, and T. M. S. Cogan. $1994 .{ }^{13} \mathrm{C}$ Nuclear magnetic resonance studies of citrate and glucose cometabolism by Lactococcus lactis. Appl. Environ. Microbiol. 60:1739-1748.

Raya, R. R., M. C. Manca de Nadra, A. Pesce de Ruiz Holgado, and G. Olivier. 1986a. Acetaldehyde metabolism in lactic acid bacteria. Milchwissenschaft 41:397-399.

Raya, R. R., M. C. Manca de Nadra, A. Pesce de Ruiz Holgado, and G. Olivier. 1986b. Threonine aldolase in Lactobacillus bulgaricus ATCC11842 and YOP12. Milchwissenschaft 41:630-632.

Riondet, C., R. Cachon, Y. Wache, G. Alcaraz, and C. Divies. 2000 Extracellular oxidoreduction potential modifies carbon and electron flow in Escherichia coli. J. Bacteriol. 182:620-626.

Robinson, R. K., and A. Y. Tamine. 1993. Manufacture of yoghurt and other fermented milks. Pages 1-48 in Modern Dairy Technology. Vol. 2. Advances in Milk Products. 2nd ed. R. K. Robinson, ed. Elsevier, London, UK.

Rödel, W., and R. Scheuer. 2000. Redox potential of meat and meat products. III. Control of redox potential during meat processing: Effects of $\mathrm{pH}$-value, sodium nitrite, sodium ascorbate, sodium lactate and oxygen. Fleischwirtsch. Int. 40:78-84.
Rowland, S. J. 1938. The determination of nitrogen distribution in milk. J. Dairy Res. 9:42-46.

Ruas-Madiedo, P., J. Hugenholtz, and P. Zoon. 2002. An overview of the functionality of exopolysaccharides produced by lactic acid bacteria. Int. Dairy J. 12:163-171.

Singh, H., M. A. Drake, and K. R. Cadwallader. 2003. Flavor of Cheddar cheese: A chemical and sensory perspective. Comp. Rev. Food Sci. Food Saf. 2:139-162.

Smit, G., B. A. Smit, and W. J. M. Engels. 2005. Flavour formation by lactic acid bacteria and biochemical flavour profiling of cheese products. FEMS Microbiol. Rev. 29:591-610.

Tamine, A. Y., and V. M. E. Marshall. 1997. Microbiology and technology of fermented milks. Pages 57-152 in Microbiology and Biochemistry of Cheese and Fermented Milk. 2nd ed. B. A. Law, ed. Blackie Academic and Professional, London, UK.

Tamine, A. Y., and R. K. Robinson. 1988. Fermented milks and their future trends. Part II. Technologicals aspects. J. Dairy Res. $55: 281-307$.

Tamine, A. Y., and R. K. Robinson. 1999. Yoghurt: Science and Technology. CRC Press, Washington, DC.

van Dijk, C., T. Ebbenhorst-Selles, H. Ruisch, T. Stolle-Smits, E. Schijvens, W. van Deelen, and C. Boeriu. 2000. Product and redox potential analysis of sauerkraut fermentation. J. Agric. Food Chem. 48:132-139.

Wang, X.-D., G. Mauvais, R. Cachon, C. Divies, and G. Feron. 2000 Addition of reducing agent dithiothreitol improves 4-decanolide synthesis by the genus Sporidiobolus. J. Biosci. Bioeng. 90:338340 . 